\title{
Treatment of Cotton Fabrics to Inhibit Bacterial Effect of Some Microorganisms Part I: Using Separate Nano Antibacterial Agents
}

\author{
E. A. El-Alfy, M. Attya* and M.F. Shaaban
}

Textile Research Division, National Research Center, Dokki, Cairo and "National Water Research Centre, Kanater, Kalubia, Egypt.

\begin{abstract}
7 REATMENT of GMA-grafted-cotton fabric with different Nano-oxides and Nano-salts such as $\mathrm{TiO}_{2}, \mathrm{ZnO}$ and $\mathrm{AgNO}_{3}$ to improve its antibacterial property, was the goal of this study, the obtained results estimated via SEM and antibacterial activity measurement assured that an enhancement was obtained in both antibacterial against gram negative bacteria (Escherichia coli) and gram positive bacteria (Staphylococcus aurous) which is better than the normal treatment when using these techniques.
\end{abstract}

Keywords: Grafting, Antibacterial activity, Cotton, Co-polymerization, GMA and Nano-oxides.

Graft copolymers based on natural polymers like cellulose and chitosan have attracted significant research interest in the past years because of the abundant and renewable polymer resource worldwide. Moreover, these natural polymers are available in large amounts and typically cheap. The use of various graft copolymers and networks based on cellulose and other natural polymers is an area actively explored in the field of active polymer supports for metal ion sorption and enzyme immobilization ${ }^{(1,2)}$.

Graft copolymerization is a common and well-established method for chemical modification of surfaces of natural and synthetic polymers ${ }^{(3-7)}$.

Initiation of grafting process can be achieved using several techniques. Some of these techniques are discussed in a review ${ }^{(7)}$ and these consist of chemically initiated grafting, photochemical initiation, plasma-initiated polymerization, enzymatic grafting, living radical polymerization and grafting by high-energy ionizing radiation. The choice of monomer to be grafted onto a polymer substrate depends on the target application of the grafted material. Glycidyl methacrylate (GMA) is a well-known monomer used by several researchers ${ }^{(8-11)}$. Its reactive epoxide group allows post grafting modification to introduce functional groups on the trunk polymer. After reaction with various reagents, the epoxide ring opens and generates reactive groups for ion exchange or chelate formation.

Recent advances in nanoscience and nanotechnology have tremendous impact on almost all industries and many segments of daily life. A large number 
(more than thousand) of labeled commercial products (electronic, automotive, medical, cosmetics, optics, etc.) contain different nanoparticles (NPs) ${ }^{(12,13)}$. Ag NPs are currently the most commonly used nano-engineered material due to their outstanding antimicrobial activity ${ }^{(14)}$. However, the potentials of metal oxide nanoparticles, in particular $\mathrm{TiO}_{2} \mathrm{NPs}$, offer broader application ${ }^{(15)}$. This photocatalyst can be efficiently utilized for self-cleaning of surfaces, water and air purification ${ }^{(16)}$. The positive experience in familiar fields and the prospects of good technical and economic success were promptly recognized by textile industry and thus, the finishing of textile materials with $\mathrm{AgNO}_{3}, \mathrm{TiO}_{2}$ and $\mathrm{ZnO}$ NPs became the focus of many research groups worldwide during the last decade. Numerous studies on $\mathrm{Ag} \mathrm{NO}_{3} \mathrm{NPs}$ application to textile surfaces and increasing microbial resistance to various available antibiotics facilitated the commercial manufacturing of textile goods with antimicrobial properties which were readily accepted by consumers ${ }^{(17)}$. At the same time, the interest for $\mathrm{TiO}_{2}$ NPs immobilization onto textile materials is continually growing due to their extraordinary photocatalytic activity, nontoxicity, high availability, biocompatibility, and low price ${ }^{(18)}$. Actually, the crucial point is that $\mathrm{TiO}_{2} \mathrm{NPs}$ simultaneously impart antibacterial, UV protective and self-cleaning properties to textile materials. Taking into account ever growing consumer demands, the fact that small amount of $\mathrm{TiO}_{2}$ NPs provides desirable effects as well as relatively simple routes for their synthesis and further processing, it becomes clear why such multifunctional nanocomposite textile materials are of interest for textile industry. However, unlike textile goods with incorporated Ag NPs that are already available in the market, textiles modified with $\mathrm{TiO} 2 \mathrm{NPs}$ are still on the level of exploration. In spite of their numerous potential applications and evident benefits, there are several concerns which inhibit commercialization of such products requiring further research.

The present work applies $\mathrm{TiO}_{2}, \mathrm{ZnO}$ and $\mathrm{AgNO}_{3}$ NPs separately to the grafted cotton fabric to enhance the antibacterial activity of the grafted cotton fabrics.

\section{Experimental}

\section{Fabrics}

Raw woven cotton fabrics of $200 \mathrm{~g} / \mathrm{m} 2$ (was kindly supplied by El-Nasr company ( Mehalla Kubra, Gharbia, Egypt), were scoured by boiling in $10 \mathrm{~g} / \mathrm{l}$ of sodium carbonate solution and $2 \mathrm{~g} / \mathrm{l}$ nonionic detergent (Cibapon® R- Ciba )at $90^{\circ} \mathrm{C}$ for 60 min using liquor ratio 50:1, then rinsed with hot and cold water successively then neutralized by $1 \%$ acetic acid solution and finally dried.

\section{Chemicals}

Glycidyl Methacrylate (GMA) (Fluka), silver nitrate, titanium dioxide, zinc oxide, caustic soda, acetic acid, sodium carbonate and sodium bisulphite were all of analytical grade chemicals, the acetone sodium bisulphite (ASBS) adduct was prepared according to a prescribed method ${ }^{(19)}$.

Egypt. J. Chem. 58, No. 6 (2015) 


\section{Grafting procedure}

Cotton fabric was grafted using (GMA) monomer according to the method mentioned else-where ${ }^{(20)}$.

\section{Treatments of cotton fabrics}

Using exhaustion method

Different concentrations (0.5 - $1.0 \%$ o.w.f) of the antibacterial agents such as $\mathrm{TiO}_{2}, \mathrm{ZnO}$ and $\mathrm{AgNO}_{3}$ were used in the nanoform to treat the grafted cotton fabrics separately. The concentrations were added during grafting process with liquor ratio (20:1), $\mathrm{pH}$ 6, for $180 \mathrm{~min}$ at $25^{\circ} \mathrm{C}$ using a shaking water bath. Finally, at the end of reaction the treated cotton fabric washed thoroughly with distilled water, dried at $90^{\circ} \mathrm{C}$, then cured at $110^{\circ} \mathrm{C}$ for 1 min weighed and tested against gram positive and gram negative bacteria.

\section{Using padding method}

The grafted cotton fabric was padded into solutions of ( $5 \mathrm{~g}$ and $10 \mathrm{~g} / \mathrm{l}$ ) of the nano antibacterial agents separately using lab Padder with a pick up $100 \%$ and pressure of $1 \mathrm{bar}$ then cured at $110^{\circ} \mathrm{C}$ for $1 \mathrm{~min}$, washed thoroughly with distilled water, dried at $90^{\circ} \mathrm{C}$, weighed and tested against microorganisms.

\section{Instrumental analysis}

SEM-Macrograph

The surface morphologies of the functionalized cottons at various stages were characterized by using a JEOL JSM 840A (Tokyo, Japan), Scanning Electron Microscope (SEM) at an accelerating voltage of $15 \mathrm{KV}$.

\section{Antibacterial activity}

To evaluate the antibacterial activity for gram-positive and gram-negative bacteria we used AATCC and AATCC6538p methods. Seven samples named S1-S7 each contains $0.5 \mathrm{gm}$ of sterilized sample mixed with $100 \mathrm{ml}$ of 106 $\mathrm{CFL} / \mathrm{ml}$ bacteria solution respectively. Putting the mixture in a conical flask and cultured in a shaker incubator at $37^{\circ} \mathrm{C}$ for $24 \mathrm{hr}$. With $120 \mathrm{rpm}$. S1 used as the control sample, where S2-S7 considered the test samples. We diluted the bacteria culture solutions by a factor of 104 using the ten-time dilution method, then, $1 \mathrm{ml}$ of each diluted bacterial solutions mixed with $15 \mathrm{ml}$ nutrient agar and placed into Petri dishes. After mixing and coagulation the samples cultured at $37^{\circ} \mathrm{C}$ for $24 \mathrm{hr}$, the colony count on the plate then calculated using the following formula:

$$
\text { Percentage of viale Cell }=\mathrm{K} / \mathrm{K}_{0}
$$

where $\mathrm{K}_{0}$ is the control colony count and $\mathrm{K}$ is $\mathrm{S} 2$-S5 colony count. 


\section{Results and Discussions}

Antibacterial treatment using $\mathrm{AgNO}_{3} \mathrm{NPs}$

The results as appeared from Fig. $1 \& 2$ and Table $1 \& 2$,it is noticed that silver nitrate has great activity against Escherichia coli and Staphylococcus aurous and the activity for silver is increased by increasing the concentration of silver nitrate.

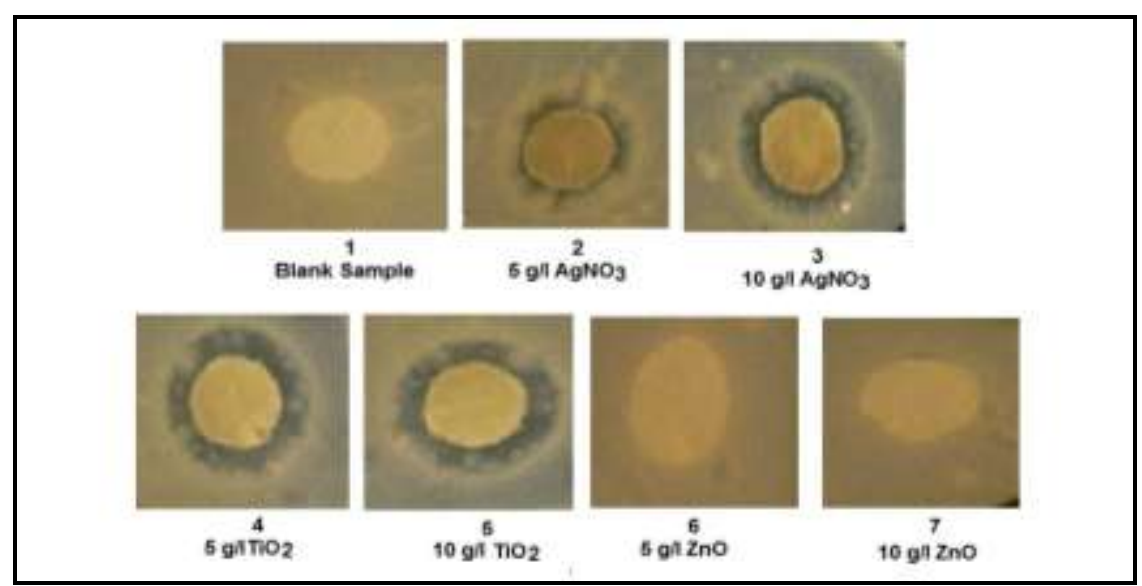

Fig. 1. Effect of treating grafted cotton fabrics on eschrichia coli using padding method.

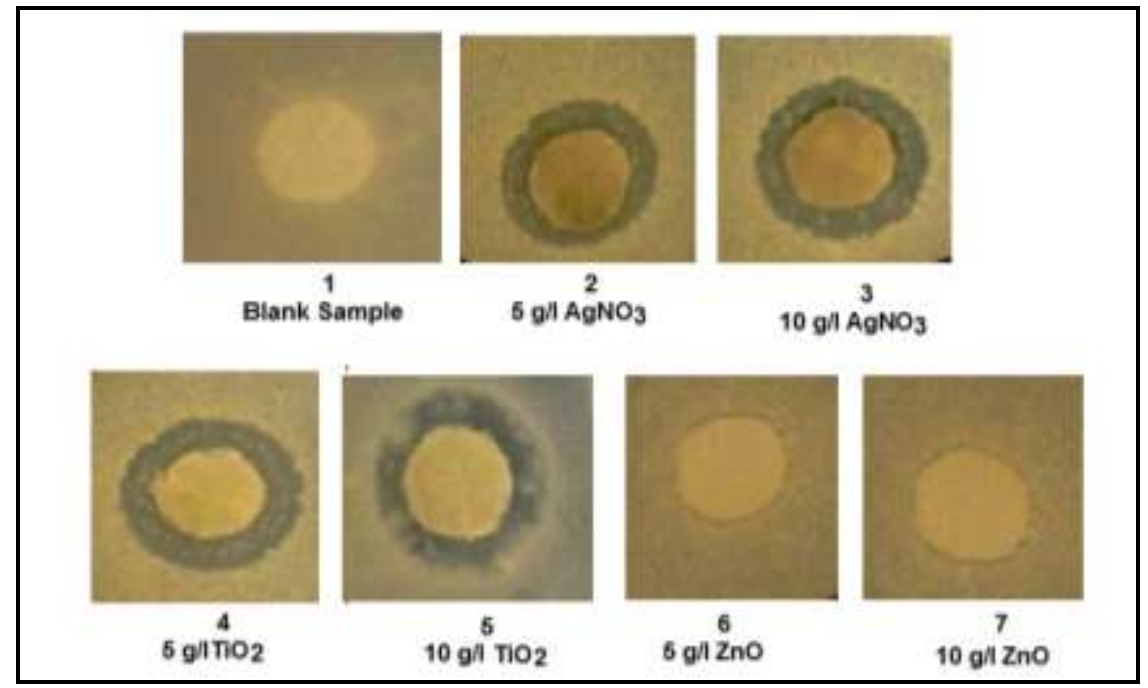

Fig. 2. Effect of treating grafted cotton fabrics on Staphlococcus aureus using padding method.

Egypt. J. Chem. 58, No. 6 (2015) 
TABLE 1. Effect of different antibacterial agents on the activity of Escherichia coli and Staphylococcus aurous using padding method.

\begin{tabular}{|c|c|c|c|}
\hline \multirow{2}{*}{$\begin{array}{l}\text { Sample } \\
\text { No. }\end{array}$} & \multirow[b]{2}{*}{ Treatments } & \multicolumn{2}{|c|}{$\begin{array}{c}\text { Inhibition Zone Diameter }(\mathrm{mm} / \mathrm{cm} \\
\text { Sample) }\end{array}$} \\
\hline & & Escherichia coli & $\begin{array}{l}\text { Staphylococcus } \\
\text { aurous }\end{array}$ \\
\hline 1 & Blank Sample & 00 & 00 \\
\hline 2 & $5 \mathrm{~g} / \mathrm{AgNO}_{3}$ & 14 & 18 \\
\hline 3 & $10 \mathrm{~g} / 1 \mathrm{AgNO}_{3}$ & 16 & 20 \\
\hline 4 & $5 \mathrm{~g} / 1 \mathrm{TiO}_{2}$ & 18 & 20 \\
\hline 5 & $10 \mathrm{~g} / \mathrm{TiO}_{2}$ & 18 & 20 \\
\hline 6 & $5 \mathrm{~g} / \mathrm{l} \mathrm{ZnO}$ & 11 & 12 \\
\hline 7 & $10 \mathrm{~g} / \mathrm{ZnO}$ & 11 & 11 \\
\hline
\end{tabular}

TABLE 2. Effect of different antibacterial agents on the activity of Escherichia coli and Staphylococcus aurous using exhaustion method.

\begin{tabular}{|c|c|c|c|}
\hline \multirow{2}{*}{$\begin{array}{c}\text { Sample } \\
\text { No. }\end{array}$} & Treatments & \multicolumn{2}{|c|}{$\begin{array}{c}\text { Inhibition } \\
\text { Zone Diameter }(\mathbf{m m} / \mathrm{cm} \\
\text { Sample) }\end{array}$} \\
\cline { 3 - 4 } & Blank Sample & 00 & 00 \\
\hline 1 & $0.5 \% \mathrm{AgNO}_{3}$ & 12 & 16 \\
\hline 2 & $1.0 \% \mathrm{AgNO}_{3}$ & 14 & 17 \\
\hline 3 & $0.5 \% \mathrm{TiO}_{2}$ & 17 & 19 \\
\hline 4 & $1.0 \% \mathrm{TiO}_{2}$ & 17 & 18 \\
\hline 5 & $0.5 \% \mathrm{ZnO}_{\text {aurous }}$ \\
\hline 6 & $1.0 \% \mathrm{ZnO}$ & 9 & 10 \\
\hline 7 & & 9 & 11 \\
\hline
\end{tabular}

It is believed that the silver ions bind disulfide (S- S), and sulfhydryl (- $\mathrm{SH}$ ) groups in the microbial cell wall's protein resulting in the disruption of metabolic processes, and ultimately in the cell death ${ }^{(20)}$. Also, it was proposed that silver ions can interact with phosphorous moieties in DNA, resulting in inactivation of 
DNA replication that leads to the inhibition of enzyme functions ${ }^{(21)}$. Padding process afforded better results in padding more than exhaustion method.

Antibacterial treatment using $\mathrm{TiO}_{2} \mathrm{NPs}$

In previous study ${ }^{(22)}$ it was reported that the antibacterial properties of $\mathrm{TiO}_{2}$ was attributed to the high redox potential of the surface species, affording nonselective oxidation of bacteria. Also, the antimicrobial properties of $\mathrm{TiO}_{2}$ derive from its photo catalytic killing of microbes ${ }^{(23,24)}$, better results were obtained compared with silver nano particles. The same observation was found.

\section{Antibacterial treatment using $\mathrm{ZnO} N \mathrm{NP}$}

The data obtained in Tables $1 \& 2$ and Fig. 1 - 4 showed that cotton fabric treated with nano zinc oxide has antibacterial activity against Escherichia coli and Staphylococcus aurous.

The mode of action for zinc oxide NPs on Staphylococcus aurous and Escherichia coli can be explained by binding to certain components in the cell wall of microorganisms and cut off the flow of oxygen into the cell therefore the cell can't carry out the respiration and will die. This mode of action is inherently quick and is exclusive to the unicellular microorganisms ${ }^{(24)}$. Despite the apparent antibacterial activity of the grafted fabric on applying ZnO NPs.,its improvement is still lower than the effect of $\mathrm{TiO} 2$ and $\mathrm{AgNO} 3 \mathrm{NPs}$ regardless of the antibacterial activity.

Evaluating the susceptibility of bacterial species to different antibacterial agents

The purpose of the present study or test is to obtain more information about the best antibacterial agents which can be used in cotton textiles for protection and the best method for adding this agents where the whole samples of the previous treatments were tested against Escherichia coli (Gram negative bacteria) and Staphylococcus aurous (Gram positive bacteria) where the sensitivity of bacterial strain can determine the best agent and methods.

Results of Fig. 1- 4 and Tables $1 \& 2$ showed that:

For Gram negative bacteria (Escherichia coli) the best results achieved using padding method. The antibacterial agents can be arranged in the following order.

$$
\mathrm{TiO}_{2}>\mathrm{AgNO}_{3}>\text { Nano Zinc oxide }
$$

Also, for Gram positive bacteria (Staphylococcus aurous) using padding method

$$
\mathrm{TiO}_{2}>\mathrm{AgNO}_{3}>\text { Nano Zinc oxide }
$$




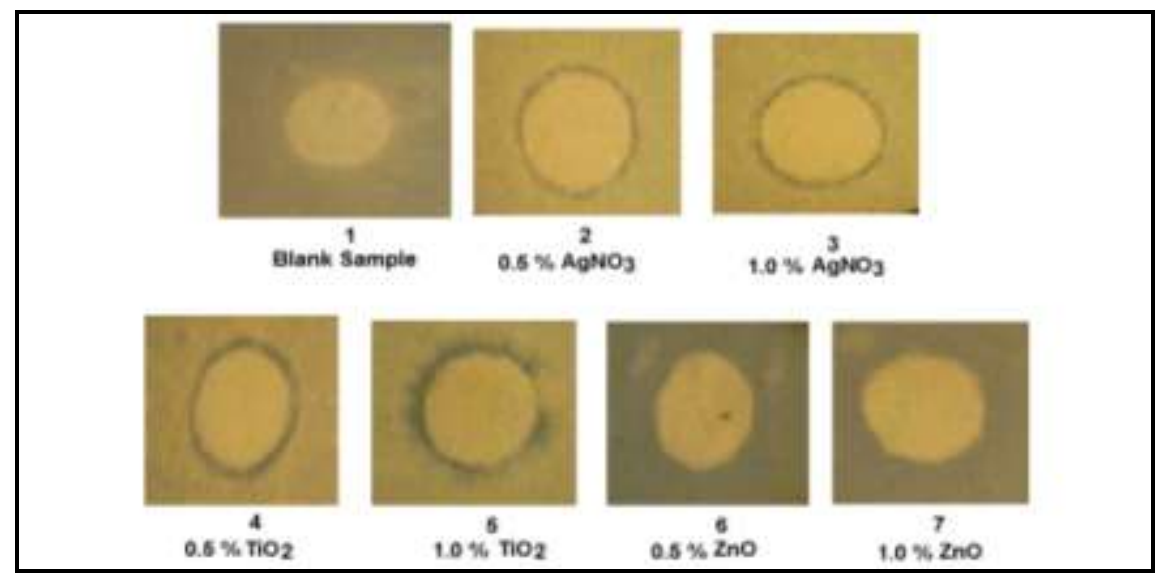

Fig. 3. Effect of treating grafted cotton fabrics on Eschrichia coli using exhausion method.

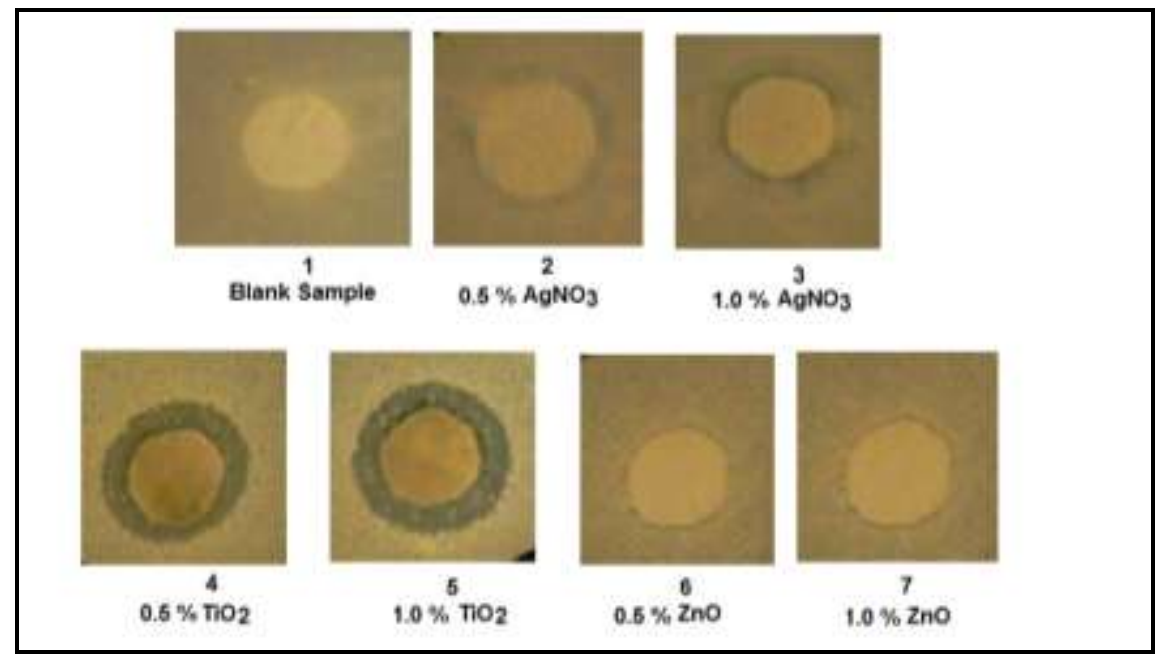

Fig. 4. Effect of treating grafted cotton fabrics on Staphlococcus aureus using exhausion method.

\section{Conclusion}

Grafting of bleached woven cotton fabric using glycidyl methacrylate monomer (150\% o.w.f) in presence APS/ASBS as initiator was carried out at an ambient temperature followed by treatment with different antibacterial agents to enhance the ability of the cotton fabric to withstand the gram positive and gram negative bacteria. Different antibacterial agents such as, $\mathrm{AgNO}_{3}, \mathrm{TiO}_{2}$ and $\mathrm{ZnO}$ NPs, were utilized to achieve the required goal and the antibacterial activity 
against gram positive and gram negative bacteria illustrated that grafting process prior treatment using padding technique has a prolonged effect on enhancing the antibacterial activity of grafting cotton fabrics rather than treatment during the grafting (Exhaustion process), i.e. while both techniques afforded good antibacterial effect against gram positive and gram negative bacteria and the padding technique presents better results in inhibiting bacterial growth.

\section{References}

1. Shaaban, M.F., Attia, M. and El-Alfy, E.A., Graft copolymerization of cotton fabrics using glycidyl methacylate at low temperature. Journal of Basic and Applied Research International, 6 (1), 25-32 (2015).

2. Peter, O. B., Yan, H., Mingqing, H., Qi. Z., Jingbo, W., Jacqueline, O., Livingstone, K. , Sam, A. and Paul, O. B., Sorption of heavy metal ions onto carboxylate chitosan derivatives-A mini- review. Ecotoxicology and Environmental Safety, 116, 113-120 (2015).

3. Desmet, G., Takacs, E., Wojnarovits, L. and Borsa, J., Cellulose functionalization via high-energy irradiation-initiated grafting of glycidyl methacrylate and cyclodextrin immobilization. Radi. Phys. Chem. 80, 1358-1362 (2011).

4. Ayako, S., Noriaki, S., , Masao, T. and Yoshio, S., Biodegradable metal adsorbent synthesized by graft polymerization onto nonwoven cotton fabric. Radiation Physics and Chemistry, 79,16-21 (2010).

5. Vijay, K. T., Manju, K. T. and Raju, K. G., Graft copolymers of natural fibers for green composites. Carbohydrate Polymers, 104, 87-93 (2014).

6. Kouroush, S., Mehmet, Y., Zakir, M.O.R. and Erhan, P., Controlled graft copolymerization of lactic acid onto starch in a supercritical carbon dioxide medium. Carbohydrate Polymers, 114, 149-156 (2014).

7. Wojnarovits, L., Foldvary, C. M. and Takacs, E., Radiation-induced grafting of cellulose for adsorption of hazardous water pollutants: A review. Radiation Physics and Chemistry, 79, 848-862 (2010).

8. Aline, B. D., Cristina, A. D., Ana, M. G. P. and Rommel, B. V., The effect of the polymerization initiator and light source on the elution of residual Bis-GMA and TEGDMA monomers: A study using liquid chromatography with UV detection. Spectrochimica Acta Part A: Molecular and Biomolecular Spectroscopy, 151, 908-915 (2015).

9. Ping, X., Weiguang, S., Yaohua, G., Haifeng, L. and Julan, W., Hydrophilic porous magnetic poly(GMA-MBAA-NVP) composite microspheres containing oxirane groups: An efficient carrier for immobilizing penicillin G acylase. Journal of Magnetism and Magnetic Materials, 378, pp. 306-312 (2015).

10. Minakshi, S. G. and Deepak, S., Effect of glycidyl meth acrylate (GMA) content on thermal and mechanical properties of ternary blend systems based on cardanol-based

Egypt. J. Chem. 58, No. 6 (2015) 
vinyl ester resin, styrene and glycidyl methacrylate. Progress in Organic Coatings, 77 (7), 1208-1220 (2014).

11. Rajeev, K. S., Lalita, Anirudh P. S. and Ghanshyam, S. C., Grafting of GMA and some comonomers onto chitosan for controlled release of diclofenac sodium. International Journal of Biological Macromolecules, 64, 368-376 ( 2014).

12. Maja, R., Functionalization of textile materials with $\mathrm{TiO}_{2}$ nanoparticles. Journal of Photochemistry and Photobiology C: Photochemistry Reviews, 16, 62-76 (2013).

14. Shahidi, S. and Wiener, J., Antibacterial Agents in Textile Industry, Book of Biochemistry Genetics and Molecular Biology, Chapter 19. Intec. 387-406 (2012).

15. Chawengkijwanich, C. and Hayata, Y., Development of $\mathrm{TiO}_{2}$ powder-oated food pakaging film and its ability to inactivate Escherihia Coli in vitro and in actual tests. Inter. J. Food Microbil. 123, 288-292 (2008).

16. Maryan, A. S., Montazer, M., Harifi, T. and Rad, M. M., Aged-look vat dyed cotton with anti-bacterial/anti-fungal properties by treatment with nano clay and enzymes. Carbohydrate. Polymer, (95), 338- 347 (2013).

17. Verma, Y., Acute toxicity assessment of textile dyes and textile and dye industrial effluents using daphnia magna bioassay. Toxicol. Ind. Health. 24, 491-501 (2008).

18. Aruoja, V., Dubourguier, H. C., Kasemets, K. and Kahru, A., Toxicity of nanoparticles of $\mathrm{CuO}, \mathrm{ZnO}$ and $\mathrm{TiO}_{2}$ to micro algae pseudokirchneriella subcapitata. Sci. Total Environ. 407, 1461-1468 (2009).

19. Shaaban, M. F., Synthesis, characterization and utilization of new ion exchangers based on cellulose. Ph.D. Thesis, Fac. Sci., Helwan Univ., Egypt (2007).

20. Uddin, F., Environmental concerns in antimicrobial finishing of textiles. Inter. J. Text. Sci. 3 (1A), 15-20 (2014).

21. Hosseinzadeh, H. and Mohammadi, S., Durable antibacterial finish on cotton fabric using hydrogels-silver nanocomposite. Curr. Chem. Lett. (2), 109-118 (2013).

22. Matsunaga, T., Tomoda, R., Nakajima, T. and Wake, H., Photochemical sterilization of microbial cells by semiconductor powders FEMS Microbiol. Lett. 29, 211-223 (1985).

23. Mills, A., Hodgen, S. and Lee, S. K., Self-cleaning Titania films: An overview of direct, lateral and remote photo- oxidation process. Res. Chem. Intermed. 31, 295-308 (2005).

24. Simoncic, B. and Tomsic, B., Structures of novel antimicrobial agents for textiles - A Review. Text. Res. J. 80 (16), 1721- 1737 (2010). 


\section{معسالجة الأقمشة القطنية لمنـع تأثير البكتريا الجزء الأول: باستخدام مواد نانوية مقاومـه للبكتريا}

$$
\begin{aligned}
& \text { اخلاص عبد ربه الألفى , محمد عطيه" و محمد فكرى شعبان }
\end{aligned}
$$

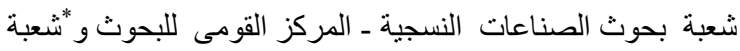

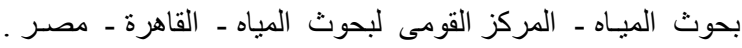

تم اجر اء التجارب على أقششة القطن المنسوج المبيض عن طريق تطعيمه بمونومر

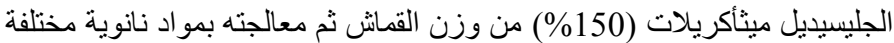

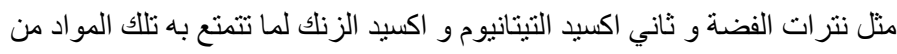

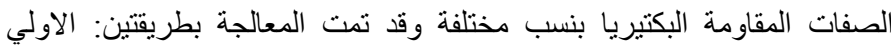

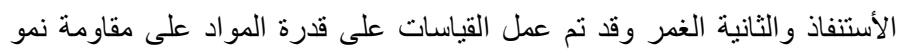

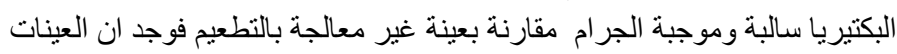

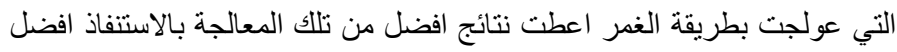

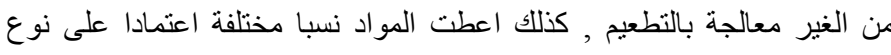

$$
\mathrm{TiO}_{2}>\mathrm{AgNO}_{3}>\text { Nano Zinc oxide }
$$

